\title{
A critical analysis of Pier Paolo Pasolini's African Oresteia
}

\author{
Kim Michaelis \\ Department of Modern Languages and \\ Literatures (Italian Studies) \\ University of the Witwatersrand \\ JOHANNESBURG
}

\begin{abstract}
A critical analysis of Pier Paolo Pasolini's African Oresteia

Pasolini's Appunti per un'Orestiade africana (1970) is a metaphorical film, inspired by the Greek legend of Orestes, in which Pasolini views postcolonial African history through the lens of mythology. His portrait of the birth of "modern" Africa is an attempt to narrate the passage from past to present and to salvage "prehistory" through his dream of the unification of the rational, democratic state and the irrational, primal state of being. It is, however, a dream punctuated by contradictions and paradoxes, a dream which Pasolini will later abandon. Yet it is significant in the overall development of Pasolini's genre.
\end{abstract}

\section{Pasolini's encounter with prehistory}

Many of Pasolini's works of the late 1960s and early $1970 \mathrm{~s}^{2}$ deal with his search, in the Third World, for an altenative to the present neo-capitalist world which Pasolini abhorred. He sees the Third World as a prehistoric world apart, with its people "living in a sort [...] of political substratum, a sort of rustic world-in-itself, noble in its own way" (Pasolini, 1960:196). Prehistory, for Pasolini, is

... propelled by dark and savage impulses that well up from the unconscious of individuals and from mankind's archaic past. History gives way to myth as the linear time of Christianity is eclipsed by what Mircea Eliade - the famous cthnologist much admired by Pasolini - calls the 'eternal return' of earlier religions (Greene, 1990:127).

1 A first version of this paper was read at the VIII International A.P.I. (Association of Professional Italianists) Congress, Cape Town, 6-8 September 1993

2 Some cxamples include: Soprahoghi in Palestina (1964); Appunti per un film sull India (1968); Appunti per una Orestiade africana (1970); a collection of articles entitled "L'adorc dell'India" (1962); a screcnplay for an unrealised film: II padre selvaggio (1975). 
Pasolini's anathema of neo-capitalist society together with his fascination for the permanence of great myths in modern life inspires him to visit Third World countries and to weave his love of these places into cinematic depictions of archaic civilisations. His urgent need to find civilisations which were uncontaminated by bourgeois consumerism grew as he felt repelled by the new Italy emerging around him. This longing led his search for a myth of the past to the Africa envisioned in his film, the Appunti per un'Orestiade africana $(1970)^{3}$, a documentary made for Italian television. Pasolini believed Africa to be the polar opposite of the horrendous universe of neo-capitalism.

Against the backdrop of Pasolini's love-hate relationship with authority, be it the Catholic Church or consumer society, the Third World gave him the means against which to contrast the authority of all the moral and social institutions with which he clashed. The Third World gave him the new terrain to "essere cosciente della assoluta necessità di rinnovamento [...] di mettere in ballo tutto, senza paura e senza rimpianti" [be conscious of the absolute need to renew [...] to question everything, without fear and without regret] (Golino, 1985:229).

The Appunti is the preliminary filmic notes for a film (which Pasolini never made) of how he would go about making the Oresteia in Tanzania and Uganda. The film explores images and characters which would lend themselves to the mythical scenario of a filmic version of Aeschylus' Oresteia 4 . Pasolini's 'voice-over' explains his intentions. For example, a series of "spectral" and "atrocious" trees, he explains, could symbolise the Furies, for the Furies cannot be depicted by human aspects as they are "irrational and animalistic"5; Cassandra's vision of the death of Agamemnon, father of Orestes, is represented by grisly newsreel footage of the Biafran war.

3 From here on referred to as the Appunti.

4 Aeschylus' Oresteia tells of Agamemnon, King of Argo, who returns from the Trojan war. His wife, Clitemnestra, is in love with Agestus and kills Agamemnon. At that moment, Cassandra, the slave girl, has a vision of the murder. Elektra, Agamemnon and Clitemncstra's daughter is present at the crime while Orestes, their son, is far away. When Orestes returns to Argo, he and his sister take their revenge on their mother. Orestes slays his mother, but he is immediately assailed by the Furies, the goddesses of ancestral terror, which force Orestes to go into exile Apollo, the god who protects Orestes, advises him to turn to Athena, goddess of democracy, reason and of the new city of Athens. She helps Orestes, not as a goddess but rather by submitting Orestes to the judgement of other men. She thus sets up the first human tribunal. This human court of democracy and reason absolves Orestes. The Furies, the goddesses of irrationality, which have constantly hounded Orestes, are transformed by Athena into the Eumenides who will now rule the new democratic state and who will cocxist with Athena, the goddess of reason.

5 All unreferenced quotations are taken from the film. 
The problem, however, of finding this ideal state, or "(neo-) exotic Other", as one critic, Bongie calls it, is that the melancholic Pasolini

... confers reality on an object that never was, mourning it, and thereby in a way giving life to its unreality. [...] The world of oral, magic experience is at a painful remove from the subject who desires its presence. For all that he longs to come into contact with this other world, Pasolini un-realizes it, placing it at an insuperable distance from his own. [...] These are obvious ironies, signalling the a priori sterility of his neo-exoticist undertaking. It is this hopeless vacancy that Pasolini will discover in his literary and existential encounter with the Third World (Bongie, 1991:196-201).

Pasolini himself later became aware of this same reality. From a later and disappointed viewpoint, he states:

Neo-capitalism is the great object toward which the African countries are drawing without uncertainties; a socialist Third World is no more than a legend. The Third World is heading toward an industrialization that is identifiable with the neo-capitalist model, even where the governments declare themselves to be socialist and pro-communist (Pasolini in Mancini \& Perrella, 1981:47).

By the end of his life, in 1975, he appears to have ruled out every possible altemative to the world of neo-capitalism.

This analysis attempts to highlight the contradictions which reflect Pasolini's own conflict and crisis of transition which lead up to his final position of disappointment.

For Pasolini who, later, could no longer deny the global potency of neocapitalism, his dream of the Third World functions as a desperate effort of authenticity. In the Appunti he states:

I'd like the film to [be] the story of the people. [...] I want to spread the chorus through the real day to day situation. [...] Because these [African] people are so realistic and so true, they contain within them that magical and mystical element.

What is important is not the absolute truth but Pasolini's dream of the possibility of change, of transgression, the dream of direct contact with the Other; or this could entail the dream of conserving what no longer exists, of what is now absent yet necessary.

His Appunti, inspired by the Greek legend of Orestes and of Athens' transition to democracy, becomes the means by which Pasolini views post-colonial African history through the lens of mythology. 
[Pasolini] explore[s] the ways in which age-old habits of thought and being persist in the modern world - physically, as in Third World countries. [..] [He] explores the clash, the mingling, of vastly different strands of civilisation (Greene, 1990:128).

His desire to make a modern African Oresteia is motivated by some of the parallels he sees between the evolution of ancient Greek civilisation and that of contemporary Black Africa. Just as archaic Greek civilisation (embodied in the Furies who hound Orestes) gave way to the democratic state ruled by the Eumenides, so too, in the last century has Africa been in the transition from a tribal and "savage" state to one of democracy.

Pasolini's attitude to democracy, however, is conflicting for democracy bears the neo-capitalist traces that Pasolini so detested, but at the same time, it represents the necessary need for order and control. This is depicted in Athena's (the goddess of reason) words in the film which establish the first lessons of democratic history:

Citizens of Athens, you will for the first time in the world judge a crime. From now on, the people will have the right to this assembly of its own. Let not anarchy nor dictatorship ever stand before you, o citizens, but let not authority be wholly banished for no one does his duty without fear. If you respect this order always, you will live at peace within your walls as no other people in the world ever has.

The transition from an irrational to a rational state is paradoxical, for Pasolini believes that once the Furies, the goddesses of ancestral terror, are transformed into the Eumenides, they can co-exist as "dreams of the irrational element that still remains alongside the rational democracy of the new state". Bongie suggests that the Third World's "cohabitation [...] with history is nothing more that a phantasmic one, an imaginary relation between the real and the unreal" and that "to bestow upon the prehistoric a real content would be to betray its originary force. It would, we can add, be to grasp (fetishistically) what is by essence ungraspable" (Bongie, 1991:197-198).

The argument of this article is that the poignancy of this significant fictive moment (the Appunti) lies in Pasolini's attempt to salvage the hope of "il sentimento dell'altrove" [the sense of an elsewhere] (Pasolini, 1979:149). Later on, he will accept the breakdown of hope in reality. His subsequent works (II Decameron (1971); The Canterbury tales (1972), The Arabian nights (1974) explicitly contain a history of the rise of the middle class, its mutually exploitative relationship with organized religion, and "its impulse to indenture the artist or otherwise mitigate his powers of imagination" (Snyder, 1980:129). In his last film, Salo, or the one hundred and twenty days of Sodom (1975), Pasolini's dark 
vision of the world is one in which no individuality can exist, and freedom and self-liberation are incomprehensible.

\section{The force of myth}

Pasolini stood on the edge of a disappearing world of hope, on the edge of a receding prehistory of congenial co-existence.

In the Appunti, he tries to highlight the conflict between the primordial dream and the breakdown of idealism, and his use of fiction is an attempt to make us examine conflictual reality.

The Appunti's literary value is that it documents a passage in the "progress" of history. By virtue of the "reality" that he tries to depict, this work is a statement of loss, of discovery and of contradiction.

The Furies are the goddesses of man's irrational moment. [They] are destined to be defeated, to disappear. Therefore they disappear as the world of the forefathers, of the ancestral world, the ancient world, and in the film, a part of ancient Africa is destined to disappear with them.

In the Appunti there is a sense of a profound lament for a savagery lost, and the suggestion is that the transition to post-colonial democracy produces this loss. However, for Pasolini, his film must interpret contemporary reality, and furthermore, it must thrust toward the deepest levels of human reality, and attempt to express these as well.

The story of the young man who leaves the world of his father to experience the modern world, who is driven by a need for knowledge, represents the inevitable momentum of a transition from a primeval to a modern, stratified world. But the assumption of a new consciousness must and does create a spiritual crisis: when the Furies assail Orestes for the murder of his mother, Apollo, his god, says to him: "Flee and never grow weary [...] of the suffering you must undergo before you reach the land of Athena". Mythically, suffering, sacrifice and death give rise to the spiritual potentialities of human life, and are sublimated into the idea of rebirth:

[Myths are] clues to the spiritual potentialities of the human life. [...] They are the experience of life. [...] These bits of information from ancient times [...] have to do with the themes that have supported human life, $[\ldots]$ they have to do with deep inner problems, inner mysteries, inner thresholds of passage (Campbell, 1988:4-5).

Once Orestes overcomes the Furies, the new Athenian democracy is borm. The death of the father, Agamemnon, paradoxically results in new life, in a new 
democratic world. Similarly, Africa will be assailed by suffering which, according to Pasolini in the film, "must be lived and life is slow. The proceeding towards the future is without any temporal break. The labour of the people knows no rhetoric and no pause. Its future lies in its eagerness for a future and its eagerness is also a great patience".

In order to show the conflict between past and present, Pasolini awakens the world of mythology for it has a great deal to do with the process of transitions and with the recognition of throwing off the old and entering the new. As he says in the film:

The Furies who dominated the whole first part of the tragedy as Goddesses of a Tradition - a Tradition which was, precisely, full of blood and permeated by terror - are not destroyed at the end by the Goddesses of reason but transformed. Thus they remain irrational and archaic divinities; but instead of inspiring atrocious, obsessed, and degrading dreams, they reign over works of poetry, of affective imagination (Pasolini in De Giusti, 1979:80).

For Pasolini, Africa is the embodiment of this process of transformation in the 20th century, living ambiguously somewhere between its archaic (former) self and the industrialized West, and his use of mythology is to give Africa's historical transition the ancient and profound meaning found in Greek mythology:

Mythology teaches you what's behind literature and the arts, [...] It's a great, exciting, life-nourishing subject. It has a great deal to do with the initiation ceremonies [of life]. All of [life's] rituals are mythological rites (Campbell, 1988:11).

Mythology for Pasolini is a means of coming to terms with the world. But again, Pasolini's paradoxical relationship with the mythical past and the modern present comes into play, for although Pasolini's intention is to make a film based on Greek myth, he cannot lose sight of the "scandaloso rapporto dialettico che il terzo mondo instaura col mondo industrializzato, neocapitalista o marxista" [scandalous dialectical relationship that the Third World establishes with the industrialised world, be it neo-capitalist or Marxist] (Pasolini in Falaschi, 1992:394).

Paradoxically, Pasolini's use of myth is his attempt to "save" or salvage his hope and dream of prehistory even though, because of its tragic paradoxes, the prehistory is, in fact, questionable. As Frank Kermode (1967:39) says:

Myth operates within the diagrams of ritual, which presupposes total and adequate explanations of things as they are and were; it is a sequence of radically unchangeable gestures. Fictions are for finding things out, and 
they change as the needs of sense-making change. Myths are the agents of stability; fictions the agents of change. Myths call for absolute; fictions for conditional assent. Myths make sense in terms of a lost order of time, illud tempus as Eliade calls it; fictions, if successful, make sense of the here and now, hoc tempus.

\section{Africa: the locus of contrast}

Pasolini attempts to connect the Oresteia to Africa because he sees Africa as still being able to express the prehistory inherent in Greek mythology. But in his interviews with black Rome University students, who like Orestes, have left their ancestral world in order to progress towards intellectual knowledge and civilisation, Pasolini questions the relationship between the mythical past and the modern present:

Coming like Orestes to a modern world, you can learn something new and positive, but are you sure that what you learn in the Western world is positive and that what you left is negative?

One way in which Pasolini tries to resolve this contradiction is by casting a black man as Orestes. Ideally, as an African, Orestes can oppose Western knowledge with an original spirit of his own which keeps the things he learns from being mere notions for consumption.

The conflicted Pasolini was thus drawn to Africa's primal human nature, to its unspoken darkness and yet, as a marxist, he was also drawn to the light of intellect represented by some positive aspects of democracy. For example, the University of Dar Es Salaam is used to represent the Temple of Apollo for it is elegant and confident in design. African universities are the seat of the future local intelligentsia in the culture and learning of young African nations, but they display all the internal contradictions of those young African nations. Pasolini makes this evident by focusing on an "unabashed and exemplary" (his words) plaque at the University's entrance which reads: "This University is the fruit of the people and of the Government of the People's Republic of China", followed by book titles in a bookshop which Pasolini's camera slowly scans: American education today; The social education of the adolescent; Handbook for History teachers in West Africa. Pasolini clearly depicts the contradictory signs of American progressive neo-capitalism which he sees as destructive of Africa's primal being.

Continuing in this contradictory vein, Pasolini uses authentic footage of the three year Biafran war of independence where almost a million people were killed: the Biafran army leaders will represent the Greek leaders Agamemnon, Ajax and Ulysses, and the black soldiers will represent the Greek camp. The paradox of 
the Biafran war is that not only is it a metaphor of the Greek and Trojan wars, and a meta-war/symbol of all wars, but indicative of the West's negative influence on post-colonial Africa and of the clash between past and present.

Of the grisly frames of the dead and wounded lying on the ground, Pasolini says "the protagonist of my film must be the people and so the Biafran war can represent the humble Greek soldiers who are killed, tortured and in pain". Nothing could be further from the image one has of classical Greece. Yet the linking of the stately images of Ancient Greek tragedy to these modern, contradictory images seems to suggest the breakdown of Pasolini's edenic dream. The images for Agamemnon's death of a soldier being blind-folded and shot force the viewer to contrast Greek tragedy to our present-day reality. Pasolini says in the film: "The first lessons of history are depicted by the first lessons of independent Africa". These brntal images of dictatorship and anarchy contrast with the subsequent scene, in the city of Athens (represented by the Supreme Court of Dar Es Salaam) of Athena's promulgation of democracy.

The use of music further highlights the clash of civilisations: Pasolini's Oresteia is sung in an idiom of jazz by black Americans, for they embody the contradiction of the primal rhythm reconstructed within neo-capitalistic influence. Jazz is the primal rhythm reborn in an American society: often it is about loss and pain but ultimately it tells of life and survival. Pasolini chooses black Americans in particular because they encapsulate the alienated person, the sadness, but also the need for violent expression. The use of jazz sung by black Americans is his attempt to poeticise their place in the new world.

The film ends (as does the Oresteia) with the transformation of the Furies into the Eumenides: the goddesses of irrationality will coexist with Athena, the goddess of reason. The new world, now in the hands of the people, is established and primeval divinity will coexist with reason and liberty. Paradoxically, for footage of this transformation to a modern "civilised" state, Pasolini shoots a frenzied tribal and religious wedding - signs of an archaic world.

\section{Why cinema?}

Pasolini's attraction to the cinema was its promise of direct, immediate capture of that prehistoric state from which he found himself at a distance. He saw cinema as the written language of reality as it established free contact with reality:

It has been said that I have three idols: Christ, Marx and Freud. That's only a formula. In truth, my only idol is reality. If I've chosen to be a filmmaker as well as a writer, it is because, instead of expressing this reality by those symbols which are words, I preferred to express it through cinema: to express reality with reality itself (Pasolini, 1972:167). 
Based on Pasolini's concept of "cinema di poesia" 6 , the appearance of reality in its physicality is "mystical or sacred" (Deleuze, 1983:109). It is this sacredness, negated and destroyed by bourgeois history and by consumerism, that Pasolini tries to capture through cinema. The cinema still held out to Pasolini the hope

... of what he had come to see as absent from literature and its mediatory language: namely, the possibility of radical change, [...] of direct contact with the reality of the Other. [...] [The] meeting of art and action is possible because moviemaking allows for an immediate capture of reality; unlike literature, which inevitably metaphorizes and hence debilitates its object, the cinema establishes contact with the outside world (Bongie, 1991:220).

According to Pasolini, reality is not only inherently poetic but also inherently meaningful. Its meaningfulness cannot be reduced to single, specific meanings without foreshortening its essence and potential:

A tree photographed is poetic, a human face photographed is poetic because physicality is poetic in itself, it is an apparition, it is full of mystery, it is full of ambiguity, full of polyvalent meaning, because even a tree is a sign of a linguistic system. But who talks through a tree? G-d, or reality itself. Therefore the tree as a sign puts us in communication with a mysterious speaker (Pasolini in Stack, 1969:168).

The Appunti, because of the paradoxical use of myth, seems to be Pasolini's attempt to bring fiction and reality, word and world, into a closer relation. It is his attempt to achieve that which he had only written about in "cinema di poesia":

Quel sotto-film mitico e infantile [...], l'altro film, quello che l'autore avrebbe fatto anche senza il pretesto della mimesi visiva del suo protagonista: un film totalmente e liberamente di carattere espressivoespressionistico, seguendo un'ispirazione diversa e magari più autentica, si libera dalla funzione, e si presenta come 'linguaggio in se stesso', stile (Pasolini, 1972:183).

[That mythical and child-like sub-film [...], the other film, the one which the author should have made even without the visual mimesis pretext of his protagonist: a film totally and freely of an expressive-expressionistic character, which follows a diverse and perhaps more authentic inspiration, which is free from function, and which appears like 'language in itself', style.]

6 "Cincma of Poctry": the title of Pasolini's first major essay on film, delivered at the 1965

Pesaro Film Festival and reproduced in Nichols, B. (cd.) (1976:542-558). 
Whether Pasolini achieves this cinematic goal or not, what is relevant is that this work, with his other works of this period, illuminate a stage in the evolution of his genre and signified an ideological and literary transition for Pasolini. Pasolini finally moves over to the other side of his crossroads of conflict to discover the failure of his dream:

ma io, con il cuore cosciente

di chi soltanto nella storia ha vita,

potrò mai più con pura passione operare,

se so che la nostra storia è finita?

(Pasolini, "Le ceneri di Gramsci" in Macafee \& Martinengo, 1982:22-23).

['But I, with the conscious heart/of one who can only live in history,/will ] ever again be able to act with pure passion, /if I know our history is over?']

In his earlier film Edipo re (1967), based on the Greek myth of Oedipus, the Sphinx invites Oedipus to pursue the force of rational power and responsibility and self-reliant thought - for Pasolini an awareness of one's identity, being in touch with the historical moment, is essential. Oedipus, however, refuses:

Sphinx: There is an enigma in your life. What is it?

Oedipus: I don't know. I don't want to know.

In the Appuni, Pasolini recounts a tale of lost spirit through cinema in order to promote dynamic change and counter the very attitude of Oedipus which blinds forever. Pasolini's belief is that "there are moments in history when one cannot be innocent, one must be aware; not to be aware is to be guilty" (Pasolini, in Stack, 1969:31).

\section{Bibliography}

Bongie, C. 1991. Fxotic memories. Literature, colonialism and the fin de siècle. Stanford Stanford University Press

Campbell, J. 1988. The power of my/h. New York: Doubleday

De Giusti, L. (ed.) 1979. Cinema in forma di poesia. Pordenone : Cinemazero.

Deleuze, G. 1983. Cinema l: L'image-monvement Paris : Minuit

Golino, E. 1985. Il sogno di llna cosa. Bologna : Il Mulino

Greene, N. 1990. Pier Paolo Pasolini: Cinema as heresy. New Jersey : Princeton University Press

Kermode, F. 1967. The sense of an ending. Oxford : Oxford University Press

Macafee, N \& Martinengo, L. (tr) 1982. Pier Paolo Pasolini. Poems. New York. Random House.

Mancini, M. \& Perrella, G. (eds.) 1981 ('orpi e lwoghi. Rome : Riuniti.

Nichols, B. (ed.) 1976. Movies and metheds: Los Angeles: University of California Press

Pasolini, P.P. 1960. Passicme e ideologia (19+18-1958). Milan: Garzanti.

Pasolini, P.P. 1972. Empirismo eretico. Milan : Garzanti 
Pasolini, P.P. 1979. // cass. Ed. Gian Carlo Ferretti. Roma : Riuniti

Pasolini. P P. 1992. "Viaggio in Marocco", dialogue n. 16, 22 April, 1965 In Falaschi, G (ed.) I dialoghi. Rome Riuniti p. 394-395.

Snyder, Stephen. 1980. P'ier Paolo Pasolini. Boston: Twayne

Stack, O. 1969. Passolini on Pasolini: Imerviews with Osu'ald Stack. London: Indiana University Press. 
